\title{
PHF6 regulates cell cycle progression by suppressing ribosomal RNA synthesis
}

\author{
Jiadong Wang ${ }^{1 *}$, Justin Wai Chung Leung ${ }^{1}$, Zihua Gong ${ }^{1}$, Lin Feng ${ }^{1}$, Xiaobing Shi ${ }^{2}$, Junjie Chen ${ }^{1}$ \\ From Epigenetics \& Chromatin: Interactions and processes \\ Boston, MA, USA. 11-13 March 2013
}

Mutation of PHF6, which results in X-linked mental retardation disorder-Börjeson-Forssman-Lehmann syndrome, is also present in about $38 \%$ of adult T-cell acute lymphoblastic leukemias and 3\% of adult acute myeloid leukemias. However, it remains to be determined exactly how PHF6 acts in vivo and what functions of PHF6 may be associated with its putative tumor suppressor function. Here, we demonstrate that PHF6 is a nucleolus, ribosomal RNA promoter-associated protein. PHF6 directly interacts with UBF through its PHD1 domain and suppresses rRNA transcription by affecting the protein level of UBF. Knockdown of PHF6 impairs cell proliferation and arrests cells at G2/M phase, which is accompanied by increased level of phosphorylated H2AX $(\gamma$-H2AX), indicating that PHF6 deficiency leads to the accumulation of DNA damage in the cell. We found that increased DNA damage occurs at rDNA locus in PHF6deficient cells. This effect could be reversed by knockingdown UBF or over-expressing RNASE1, which removes RNA:DNA hybrids, suggesting that there is a functional link between rRNA synthesis and genomic stability at rDNA locus. Together, these results reveal that the key function of PHF6 is involved in regulating rRNA synthesis, which may contribute to its roles in cell cycle control, genomic maintenance and tumor suppression.

\footnotetext{
Author details

${ }^{1}$ Department of Experimental Radiation Oncology, The University of Texas MD Anderson Cancer Center, 1515 Holcombe Boulevard, Houston, Texas 77030, USA. ${ }^{2}$ Department of Biochemistry and Molecular Biology, The University of Texas MD Anderson Cancer Center, 1515 Holcombe Boulevard, Houston, Texas 77030, USA.
}

Published: 8 April 2013

'Department of Experimental Radiation Oncology, The University of Texas MD Anderson Cancer Center, 1515 Holcombe Boulevard, Houston, Texas 77030, USA

Full list of author information is available at the end of the article
doi:10.1186/1756-8935-6-S1-P134

Cite this article as: Wang et al:: PHF6 regulates cell cycle progression by suppressing ribosomal RNA synthesis. Epigentics \& Chromatin 2013 6(Suppl 1):P134.
Submit your next manuscript to BioMed Central and take full advantage of:

- Convenient online submission

- Thorough peer review

- No space constraints or color figure charges

- Immediate publication on acceptance

- Inclusion in PubMed, CAS, Scopus and Google Scholar

- Research which is freely available for redistribution
C Biomed Central
C Biomed Central

(c) 2013 Wang et al; licensee BioMed Central Ltd. This is an Open Access article distributed under the terms of the Creative Commons Attribution License (http://creativecommons.org/licenses/by/2.0), which permits unrestricted use, distribution, and reproduction in any medium, provided the original work is properly cited. 